\title{
Faculty Members versus Teaching Assistants as Problem-Based Learning (PBL) Facilitators: Medical Students' Perception
}

\author{
Asmaa Abdel Nasser ${ }^{1,2}$, Jawaher Mansour Al Sharfa ${ }^{3}$, Mariam Ali AL-Garni ${ }^{3 *}$, \\ Fatima Aqeel Alzubaidi ${ }^{3}$, Ashjan Salem Bahwirith ${ }^{3}$, Mariam Aqeel Alzubaidi ${ }^{4}$ and Hani Atwa ${ }^{1,5}$ \\ 'Medical Education Department, Faculty of Medicine, Suez Canal University, Egypt; \\ dr.asmaaabdelnasser@gmail.com \\ ${ }^{2}$ Medical Education Unit, Ibn Sina National College for Medical Studies, Jeddah, Saudi Arabia \\ ${ }^{3}$ Medical Intern, Ibn Sina National College for Medical Studies, Jeddah, Saudi Arabia; \\ mntjna9@gmail.com, maryamalgarni@gmail.com, fatimaaqeel.2020@gmail.com, ashjanb5@gmail.com \\ ${ }^{4}$ Fourth Year Medical Student, Ibn Sina National College for Medical Studies, Jeddah, Saudi Arabia; \\ mariam.aq099@gmail.com \\ ${ }^{5}$ Medical Education Unit, College of Medicine and Medical Sciences, Arabian Gulf University, Manama, \\ Kingdom of Bahrain; doctorhani2000@gmail.com
}

\begin{abstract}
Problem-Based Learning (PBL) is a student-centered pedagogy that depends on the principle of using real life problems as a trigger for the acquisition and integration of new knowledge through the problem-solving skills and experiences. The PBL allows medical students to develop important skills and attributes. Among the pillars of successful PBL implementation is the 'class tutor'. The PBL tutor is known as the guide or mentor for the students. Tutors prompt students with metacognitive questions and provide direction without directly telling the student what to look for and where to go for information. The aim of the study was to compare the performance of faculty members and teaching assistants in facilitating PBL sessions from the students' points of view. A comparative, cross-sectional study was conducted on ISNC medical students who attended PBL sessions with both faculty members and teaching assistants in various integrated modules. A questionnaire designed by the researchers and transformed into an online survey (through Google Forms) has been used for data collection. The descriptive statistics have been used and a p-value $<0.05$ was considered as statistically significant. A total of 348 medical students responded to the questionnaire. The data collection tool was based on a questionnaire that was analyzed for its validity and reliability and showed a high validity reflected by KMO and Barlett's test of Sphericity with a value of 0.908 (p< 0.000 ) and high reliability reflected by Cronbach's alpha with a value of 0.928 . The study participants reported that $63.5 \%$ and $79.6 \%$ of faculty members and teaching assistants, respectively, had sufficient to high performance, while $36.5 \%$ and $20.4 \%$ of faculty members and teaching assistants, respectively, had a poor or insufficient performance. No association was found between students' perception of the facilitation performance of faculty members \&teaching assistants and their demographic data. The perception of the medical students of the PBL facilitation skills of teaching assistants was more positive than the skills of faculty members. Teaching assistants are suitable PBL facilitators probably because they have a better understanding of students' needs than faculty members, being closer to them in age or their recent experience as undergraduate medical students.
\end{abstract}

Keywords: Faculty Members, Medical Students, Teaching Assistants, PBL

*Author for correspondence 


\section{Introduction}

Problem-based learning (PBL) was pioneered by Barrows and Tamblyn from the Faculty of Medicine at McMaster University in 1968 ${ }^{1}$. PBL has been utilized for over 40 years in a variety of different disciplines and has had a major impact on medical education practices $\frac{2,3}{3}$. PBL is defined by Amin and Hoon as a method of learning that challenges the students to 'learn to learn' through cooperating in groups to reach solutions to real problems $s^{4}$. PBL is a student-centered method in which participants are assigned in groups of 8 to 12 students guided by a facilitator and given tasks in the form of real-life problems relevant to those that they will face in the field of practice after graduation. Through this approach, students acquire new knowledge and skills and are expected later to apply such knowledge and skills to reach to practical solutions for similar problems ${ }^{5}$.

Among the pillars of successful PBL implementation is the class tutor' ${ }^{\prime}$. The PBL class tutor works as the guide for the students in the group. Tutors use their facilitation skills to prompt their students with metacognitive questions relevant to the problem under discussion. They provide the students with direction without lecturing them or directly telling them what to look for. The tutor is responsible for creating a student-centered learning environment in the classroom through promoting directed self-learning, stimulating the integration of students' previous knowledge, encouraging interaction between students, and providing guidance on the learning process $\frac{7.8}{\text {. }}$.

To optimize the PBL process, tutors play an important role during sessions, through which they facilitate student-centered, self-directed learning and encourage the students to do brainstorming for problem-solving ${ }^{9}$. A tutor should identify the extent of students' prior knowledge and any misconceptions regarding it after a problem has been analyzed ${ }^{10}$. Because of the high demand of tutors in each PBL session that would be both time- and labor-intensive on the faculty members, it was necessary and helpful to train Teaching Assistants (TAs) to facilitate PBL sessions. The TAs position is designed for the recent medical graduates who have substantial academic knowledge and leadership qualities required to facilitate the learning of medical students and have enough time immediately after graduation to be dedicated to this position ${ }^{11}$.
Ibn Sina National College for Medical Studies (ISNC) is the first private medical college in the Kingdom of Saudi Arabia. ISNC encompasses four health professions education programs (Medicine, Dentistry, Pharm D and Nursing). The Medicine program runs an integrated curriculum that has systems-based modules, integration and PBL. The PBL at ISNC is implemented in a hybrid manner as one of the educational strategies of the integrated system-based modules. In this study, we compared between the performance of faculty members and teaching assistants in facilitating PBL sessions from the students' points of view.

\section{Methodology}

\subsection{Study Type and Setting}

This is a comparative, cross-sectional study that was conducted on male and female medical students of the curriculum years 3, 4, 5, and 6 of the Medicine Program of ISNC. Those are the students who experienced PBL sessions with both faculty members and teaching assistants in various integrated modules.

\subsection{Sample}

Sample size was calculated as 210 students by the equation of Dawson-Saunders and Trapp ${ }^{12}$ using a $4 \%$ margin of error, a confidence interval of $95 \%$, and a population size of 1000 , with an expected response of $50 \%$. However, the questionnaire was distributed to the entire students' batches, and 348 students has responded and filled in the questionnaire.

\subsection{Instrument}

The instrument used for data collection from the study participants was a questionnaire that was developed by the researchers after an extensive review of literature and similar studies which include items that address the perception of medical students of the performance of PBL tutors in relation to the different facilitation skills. The developed questionnaire contained 11 items.

The overall impression of the students toward faculty members and teaching assistants as PBL facilitators was determined through asking the students to give a score of 1 to 10 to faculty members and teaching assistants. A score of 5 or less was considered as "poor or insufficient" 
performance, while 6 or more was considered as "sufficient to high" performance.

To determine the suitability of the questionnaire, validity and reliability studies were conducted. Validity was established through Exploratory Factor Analysis (EFA). Reliability was measured through Cronbach's alpha test.

\subsection{Data Collection}

The questionnaire was converted into an electronic format through Google Forms. The link was communicated to all Medicine Program Year 3, 4, 5, and 6 students through different social media platforms.

\subsection{Statistical Analysis}

Data was entered into the Statistical Package for Social Sciences (SPSSv.25) $\frac{13}{3}$ and descriptive analysis was conducted. The results are reported as percentage or means with standard deviations. Association of different variables are evaluated using univariate logistics.

\subsection{Ethical Considerations}

The Ethical clearance for the study was obtained from the ISNC Research and Ethics Committee (IEC Ref No.: H-16-13082020). All the participants were informed about the purpose of the study and their right to refuse participation. Ethical conduct was maintained during data collection and throughout the research process in accordance with the Helsinki Declaration ${ }^{14}$. Participation in the study was voluntary and the confidentiality of the participants was maintained as the questionnaire was provided anonymously. Each participant had the right to withdraw from the study at any point without any consequences.

\section{Results}

\subsection{Validity and Reliability Studies of the Instrument}

\subsubsection{Exploratory Factor Analysis (EFA)}

The collected responses were 348, which was adequate for analysis. Using Kaiser-Meyer-Olkin Measure of Sampling Adequacy (KMO) and Bartlett's Test of Sphericity (Table 1) revealed a value of 0.908 . This value indicated that there were sufficient items predicted by each factor. Furthermore, Bartlett's test of sphericity was statistically significant $(p<0.000)$, which indicated that the variables were significantly correlated. Therefore, this output indicated the appropriateness of the data for factor analysis.

Factor extraction revealed that the 11 items of the questionnaire could be grouped under three factors with an eigenvalue $>1.00$. The three factors that emerged from factor analysis accounted for $66.19 \%$ of the total variance.

Results of factor rotation showed that none of the 11 items of the survey was removed. This was based on finding that all the factors had three or more items an all items had a loading of $>0.30$ on relevant factor.

The factors were named according to the heaviness of loading of the statements (items) on each factor and based on the idea behind the statement (Table 2) as follows:

- Factor 1 explained $46.872 \%$ of the variance in responses, with an eigenvalue of 10.312. Four items

Table 1. Kaiser-Meyer-Olkin Measure of Sampling Adequacy (KMO) and Bartlett's Test of Sphericity

\begin{tabular}{lll}
\hline Kaiser-Meyer-Olkin Measure of Sampling Adequacy. & 0.908 \\
\hline & \multicolumn{1}{c}{ Approx. Chi-Square } & 5742.749 \\
\cline { 2 - 3 } Bartlett's Test of Sphericity & Df & 231 \\
\cline { 2 - 3 } & Sig. & $0.000^{*}$ \\
\hline
\end{tabular}

${ }^{*}$ Statistically significant 
Table 2. Factor loadings of items under the three factors (using Principal Components Analysis)

\begin{tabular}{|c|c|c|c|c|}
\hline \multirow{2}{*}{ No. } & \multirow{2}{*}{ Evaluation Items } & \multicolumn{3}{|c|}{ Components } \\
\hline & & Factor 1 & Factor 2 & Factor 3 \\
\hline \multicolumn{5}{|c|}{ Factor label: In-class activities during the tutorials: } \\
\hline 1 & $\begin{array}{l}\text { The tutor encouraged us to independently identify } \\
\text { the learning issues }\end{array}$ & 0.799 & & \\
\hline 2 & $\begin{array}{l}\text { The tutor helped us find links between different issues } \\
\text { discussed in the tutorial session }\end{array}$ & 0.789 & & \\
\hline 3 & $\begin{array}{l}\text { The tutor guided us to summarize what we had } \\
\text { learned in our own words }\end{array}$ & 0.779 & & \\
\hline 4 & $\begin{array}{l}\text { The tutor helped us comprehend the theories } \\
\text { and mechanisms underpinning different studied } \\
\text { phenomena }\end{array}$ & 0.736 & & \\
\hline
\end{tabular}

\section{Factor label: Personal and interpersonal issues:}

\begin{tabular}{cl|l}
\hline 5 & $\begin{array}{l}\text { The tutor encouraged us to consistently evaluate } \\
\text { cooperative group work }\end{array}$ & 0.735 \\
\hline 6 & $\begin{array}{l}\text { The tutor showed clear understanding of his/her } \\
\text { strengths/weaknesses as a PL tutor }\end{array}$ & 0.677 \\
\hline $7 \quad \begin{array}{l}\text { The tutor encouraged everyone to provide } \\
\text { constructive feedback on our performance during } \\
\text { group work }\end{array}$ & 0.662 \\
\hline 8 & $\begin{array}{l}\text { The tutor showed high enthusiasm to do his/her role } \\
\text { as a PBL tutor }\end{array}$ & \\
\hline Factor label: Searching for and applying information: & $\begin{array}{l}\text { The tutor stimulated us to use our knowledge in the } \\
\text { discussed problem }\end{array}$ & 0.773 \\
\hline 10 & $\begin{array}{l}\text { The tutor encouraged us to independently search in } \\
\text { different resources }\end{array}$ & \\
\hline 11 & $\begin{array}{l}\text { The tutor stimulated us to apply what we have learned } \\
\text { to similar problems }\end{array}$ & 0.764 \\
\hline
\end{tabular}


loaded on this factor. This factor has been renamed to "In-class activities during the tutorials".

- Factor 2 explained $12.008 \%$ of the variance in responses, with an eigenvalue of 2.642. Four items loaded on this factor. This factor has been renamed to "Personal and interpersonal issues".

- Factor 3 explained $7.307 \%$ of the variance in responses, with an eigenvalue of 1.608 . Three items loaded on this factor. This factor has been renamed to "Searching for and applying information".

\subsubsection{Test of Reliability}

Test of internal consistency (reliability) revealed a highly reliable tool with a Cronbach's alpha value of 0.928 .

\subsubsection{Quantitative Analysis of the Collected Data}

Three hundred eighty-four students completed the questionnaire. About two-thirds of the respondents $(64.9 \%)$ were females. The percentage of Year 5 students were the largest among all other study years (28.2\%).

Table 3. Demographic characteristics of study participants $(n=348)$

\begin{tabular}{cc}
\hline Demographic Criteria & Frequency \\
\hline Study Year & \\
\hline Year 3 & $91(26.1 \%)$ \\
\hline Year 4 & $65(18.7 \%)$ \\
\hline Year 5 & $98(28.2 \%)$ \\
\hline Year 6 & $94(27 \%)$ \\
\hline Gender & $226(64.9 \%)$ \\
\hline Female & $122(35.1 \%)$ \\
\hline Male & $21(6 \%)$ \\
\hline Previous GPA & $208(59.8 \%)$ \\
\hline $4-5$ & $119(34.2 \%)$ \\
\hline 34 & \\
\hline & \\
\hline & \\
\hline & \\
\hline & \\
\hline & \\
\hline
\end{tabular}


Table 4. Frequencies of responses of the study participants to the questionnaire items $(n=348)$

\begin{tabular}{|c|c|c|c|c|c|c|c|c|c|}
\hline \multirow{2}{*}{ No. } & \multirow{2}{*}{$\begin{array}{l}\text { Evaluation } \\
\text { Items }\end{array}$} & \multicolumn{3}{|c|}{ Faculty Members } & \multicolumn{3}{|c|}{ Teaching Assistants } & \multirow{2}{*}{$\mathrm{Chi}^{2}$} & \multirow{2}{*}{ p-value } \\
\hline & & Agree & Not Sure & Disagree & Agree & Not Sure & Disagree & & \\
\hline \multicolumn{10}{|c|}{ In-class activities during the tutorials: } \\
\hline 1 & $\begin{array}{l}\text { The tutor } \\
\text { encouraged us } \\
\text { to independently } \\
\text { identify the } \\
\text { learning issues }\end{array}$ & $\begin{array}{c}163 \\
(46.8 \%)\end{array}$ & $\begin{array}{c}81 \\
(23.3 \%)\end{array}$ & $\begin{array}{c}104 \\
(29.9 \%)\end{array}$ & $\begin{array}{c}191 \\
(54.9 \%)\end{array}$ & $\begin{array}{c}86 \\
(24.7 \%)\end{array}$ & $\begin{array}{c}71 \\
(20.4 \%)\end{array}$ & 74.5 & $0.000^{*}$ \\
\hline 2 & $\begin{array}{l}\text { The tutor } \\
\text { helped us find } \\
\text { links between } \\
\text { different issues } \\
\text { discussed in the } \\
\text { tutorial session }\end{array}$ & $\begin{array}{c}153 \\
(43.9 \%)\end{array}$ & $\begin{array}{c}101 \\
(29 \%)\end{array}$ & $\begin{array}{c}94 \\
(27 \%)\end{array}$ & $\begin{array}{c}207 \\
(59.4 \%)\end{array}$ & $\begin{array}{c}89 \\
(25.6 \%)\end{array}$ & $\begin{array}{c}52 \\
(15 \%)\end{array}$ & 93.5 & $0.000^{*}$ \\
\hline 3 & $\begin{array}{l}\text { The tutor guided } \\
\text { us to summarize } \\
\text { what we had } \\
\text { learned in our } \\
\text { own words }\end{array}$ & $\begin{array}{c}106 \\
(30.5 \%)\end{array}$ & $\begin{array}{c}140 \\
(40.2 \%)\end{array}$ & $\begin{array}{c}102 \\
(29.3 \%)\end{array}$ & $\begin{array}{c}199 \\
(57.2 \%)\end{array}$ & $\begin{array}{c}94 \\
(27 \%)\end{array}$ & $\begin{array}{c}55 \\
(15.8 \%)\end{array}$ & 74.3 & $0.000^{*}$ \\
\hline 4 & $\begin{array}{l}\text { The tutor helped } \\
\text { us comprehend } \\
\text { the theories and } \\
\text { mechanisms } \\
\text { underpinning } \\
\text { different studied } \\
\text { phenomena }\end{array}$ & $\begin{array}{c}131 \\
(37.6 \%)\end{array}$ & $\begin{array}{c}106 \\
(30.5 \%)\end{array}$ & $\begin{array}{c}111 \\
(31.9 \%)\end{array}$ & $\begin{array}{c}180 \\
(51.7 \%)\end{array}$ & $\begin{array}{c}93 \\
(26.7 \%)\end{array}$ & $\begin{array}{c}75 \\
(21.5 \%)\end{array}$ & 41.0 & $0.000^{*}$ \\
\hline
\end{tabular}

Personal and interpersonal issues:

\begin{tabular}{|c|c|c|c|c|c|c|c|c|c|}
\hline 5 & $\begin{array}{l}\text { The tutor } \\
\text { encouraged us } \\
\text { to consistently } \\
\text { evaluate } \\
\text { cooperative } \\
\text { group work }\end{array}$ & $\begin{array}{c}109 \\
(31.3 \%)\end{array}$ & $94(27 \%)$ & $\begin{array}{c}145 \\
(41.7 \%)\end{array}$ & $\begin{array}{c}141 \\
(40.5 \%)\end{array}$ & $\begin{array}{c}90 \\
(25.9 \%)\end{array}$ & $\begin{array}{c}117 \\
(33.6 \%)\end{array}$ & 17.2 & $0.004^{*}$ \\
\hline 6 & $\begin{array}{l}\text { The tutor } \\
\text { showed clear } \\
\text { understanding } \\
\text { of his/her } \\
\text { strengths/ } \\
\text { weaknesses as a } \\
\text { PBL tutor }\end{array}$ & $\begin{array}{c}92 \\
(26.4 \%)\end{array}$ & $\begin{array}{c}114 \\
(32.8 \%)\end{array}$ & $\begin{array}{c}142 \\
(40.8 \%)\end{array}$ & $\begin{array}{c}145 \\
(41.7 \%)\end{array}$ & $\begin{array}{c}102 \\
(29.3 \%)\end{array}$ & $\begin{array}{c}101 \\
(29 \%)\end{array}$ & 16.0 & $0.007^{*}$ \\
\hline
\end{tabular}


Table 4 Continued

\begin{tabular}{|c|c|c|c|c|c|c|c|c|c|}
\hline 7 & $\begin{array}{l}\text { The tutor } \\
\text { encouraged } \\
\text { everyone } \\
\text { to provide } \\
\text { constructive } \\
\text { feedback on our } \\
\text { performance } \\
\text { during group } \\
\text { work }\end{array}$ & $\begin{array}{c}103 \\
(29.6 \%)\end{array}$ & $\begin{array}{c}108 \\
(31 \%)\end{array}$ & $\begin{array}{c}137 \\
(39.4 \%)\end{array}$ & $\begin{array}{c}144 \\
(41.3 \%)\end{array}$ & $\begin{array}{c}86 \\
(24.7 \%)\end{array}$ & $118(33.9 \%)$ & 15.3 & $0.009^{\star}$ \\
\hline 8 & $\begin{array}{l}\text { The tutor } \\
\text { showed high } \\
\text { enthusiasm to } \\
\text { do his/her role } \\
\text { as a PBL tutor }\end{array}$ & $\begin{array}{c}129 \\
(37.1 \%)\end{array}$ & $\begin{array}{c}107 \\
(30.7 \%)\end{array}$ & $\begin{array}{c}112 \\
(32.2 \%)\end{array}$ & $\begin{array}{c}203 \\
(58.3 \%)\end{array}$ & $\begin{array}{c}90 \\
(25.9 \%)\end{array}$ & $55(15.8 \%)$ & 75.2 & $0.000^{*}$ \\
\hline \multicolumn{10}{|c|}{ Searching for and applying information: } \\
\hline 9 & $\begin{array}{l}\text { The tutor } \\
\text { stimulated } \\
\text { us to use our } \\
\text { knowledge in } \\
\text { the discussed } \\
\text { problem }\end{array}$ & $\begin{array}{c}157 \\
(45.1 \%)\end{array}$ & $\begin{array}{c}112 \\
(32.2 \%)\end{array}$ & $\begin{array}{c}79 \\
(22.7 \%)\end{array}$ & $\begin{array}{c}183 \\
(52.5 \%)\end{array}$ & $101(29 \%)$ & $64(18.4 \%)$ & 66.3 & $0.000^{*}$ \\
\hline 10 & $\begin{array}{l}\text { The tutor } \\
\text { encouraged us } \\
\text { to independently } \\
\text { search in } \\
\text { different } \\
\text { resources }\end{array}$ & $\begin{array}{c}182 \\
(52.3 \%)\end{array}$ & $\begin{array}{c}79 \\
(22.7 \%)\end{array}$ & $\begin{array}{c}87 \\
(25 \%)\end{array}$ & $\begin{array}{c}199 \\
(57.2 \%)\end{array}$ & $\begin{array}{c}88 \\
(25.3 \%)\end{array}$ & $61(17.5 \%)$ & 105.0 & $0.000^{*}$ \\
\hline 11 & $\begin{array}{l}\text { The tutor } \\
\text { stimulated us to } \\
\text { apply what we } \\
\text { have learned to } \\
\text { similar problems }\end{array}$ & $\begin{array}{c}126 \\
(36.2 \%)\end{array}$ & $\begin{array}{c}112 \\
(32.2 \%)\end{array}$ & $\begin{array}{c}110 \\
(31.6 \%)\end{array}$ & $\begin{array}{c}160 \\
(45.9 \%)\end{array}$ & $\begin{array}{c}88 \\
(25.3 \%)\end{array}$ & $100(28.7 \%)$ & 19.5 & $0.002^{*}$ \\
\hline
\end{tabular}

More than half of the participants $(59.8 \%)$ had a previous GPA of 4 to 5 (Table 3).

The same questions were asked to the students in the questionnaire to investigate the performance of faculty members and teaching assistants to compare the performances of the two groups.
Table 4 shows the frequencies of responses of the students to each statement in the survey. It shows that the perception of the students is more positive towards the teaching assistants. All the differences are statistically significant $(p<0.05)$.

Figures 1-3 show the comparison of students' perception of faculty members' and teaching assistants' 


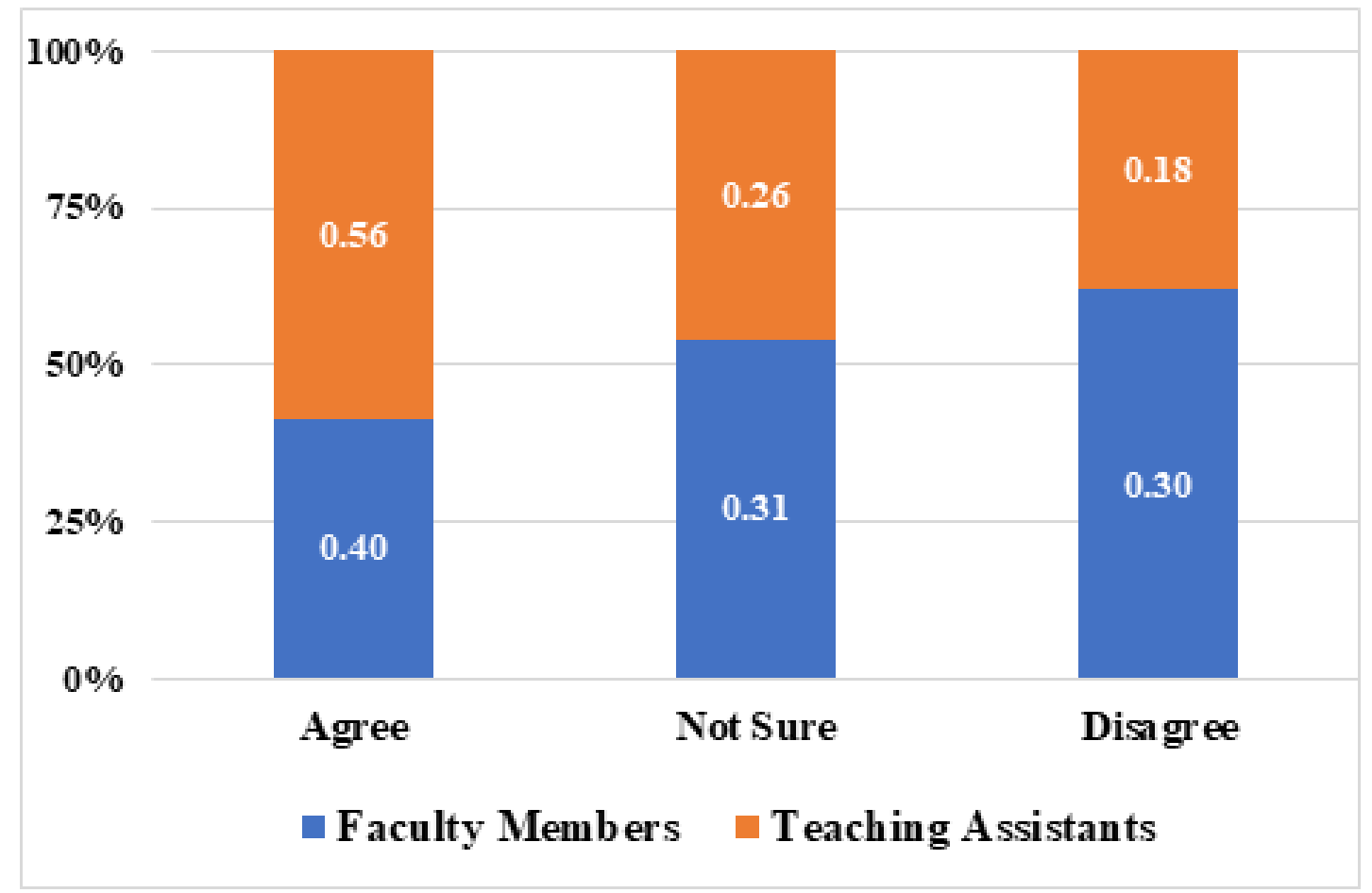

Figure 1. Comparison of students' perception of faculty members' and teaching assistants' facilitation skills related to "In-class activities during the tutorials" ( $n=348$ ).

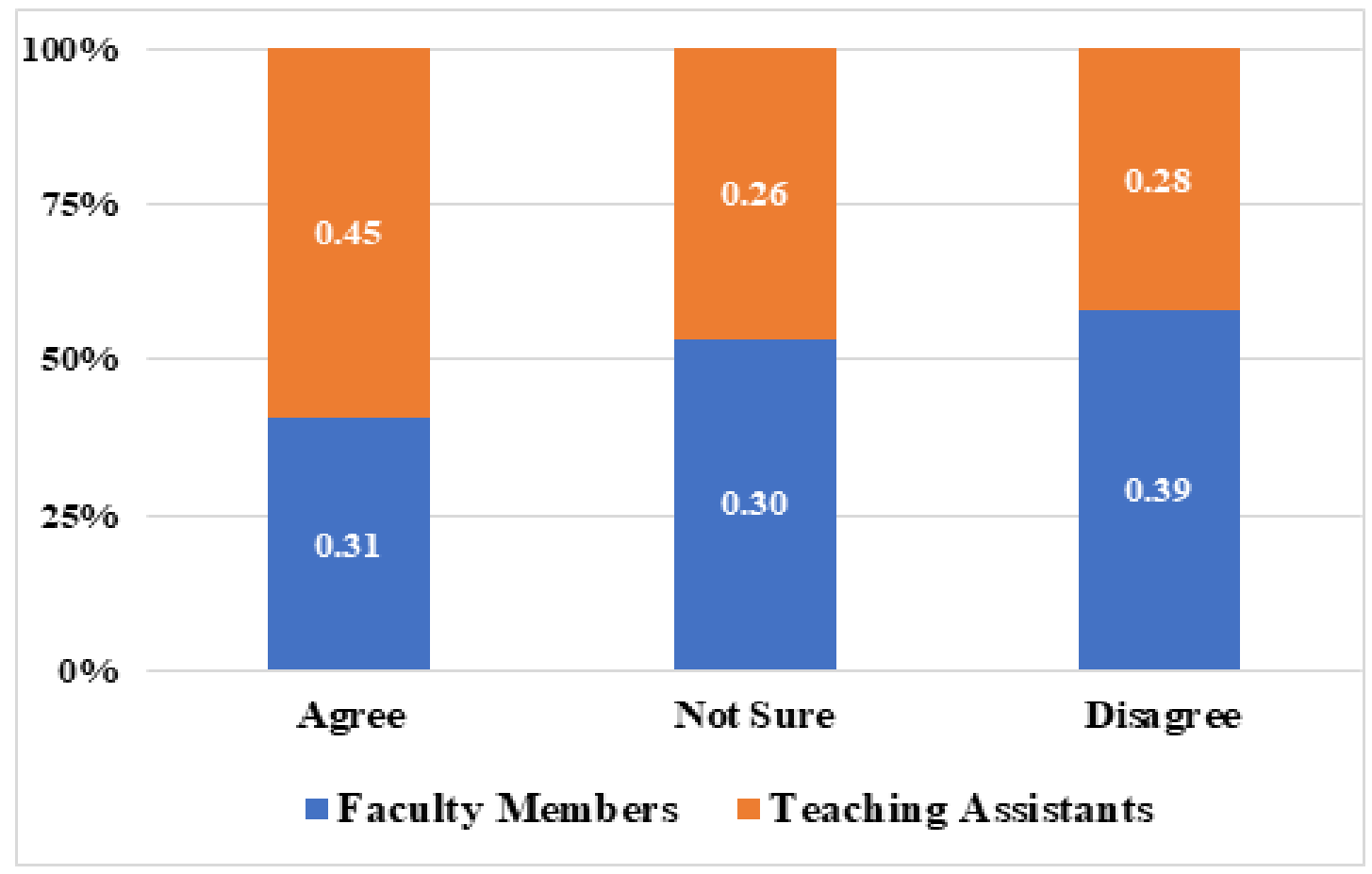

Figure 2. Comparison of students' perception of faculty members' and teaching assistants' facilitation skills related to "Personal and interpersonal issues" ( $n=348)$. 


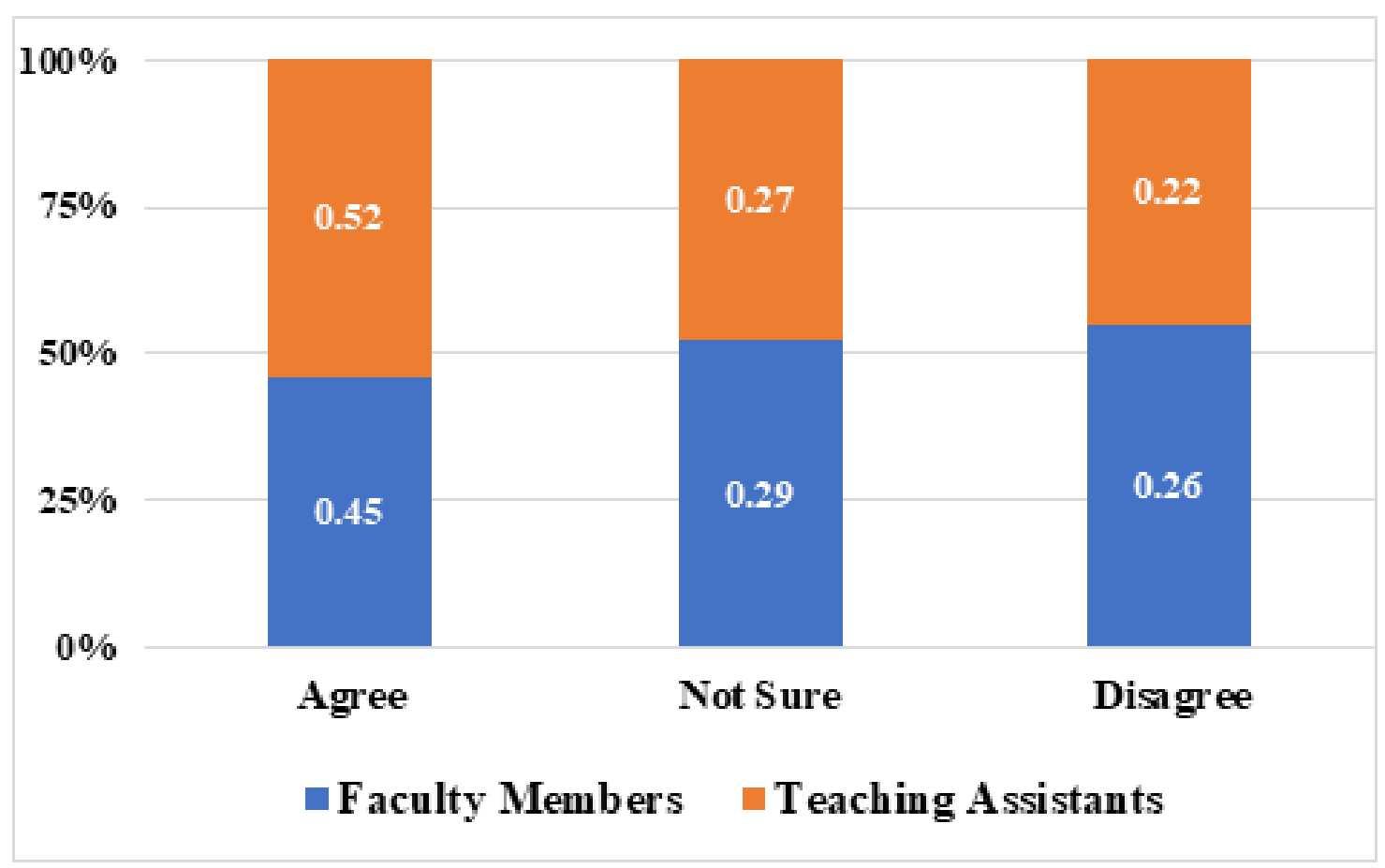

Figure 3. Comparison of students' perception of faculty members' and teaching assistants' facilitation skills related to "Searching for and applying information" $(n=348)$.

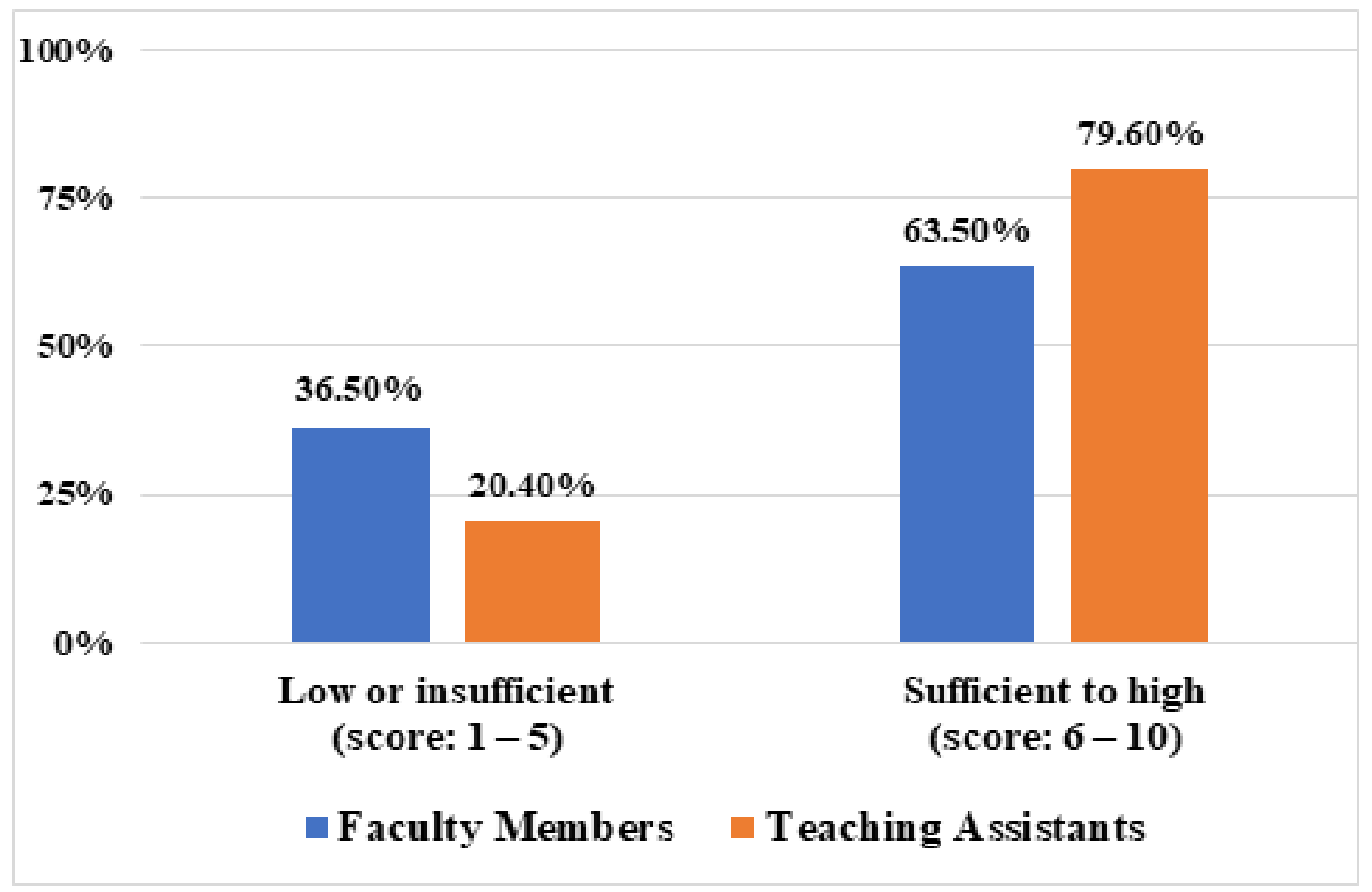

Figure 4 Comparison of the level of performance of faculty members versus teaching assistants as reported by the students $(n=348)$. 
facilitation skills related the three factors identified from factor analysis: namely "In-class activities during the tutorials", "Personal and interpersonal issues", and "Searching for and applying information". It is shown that the study participants perceived the facilitation skills of the teaching assistants more positive than those of faculty members in all evaluated domains.

The comparison of the overall performance of the faculty members and teaching assistants are shown in
Figure 4. More teaching assistants (79.6\%) than faculty members (63.5\%) have sufficient to high-performance as reported by the students.

Tables 5 and 6 show the demographic criteria as factors that might affect the perception of the students of the PBL facilitation skills of both faculty members and teaching assistants. There were no significant differences regarding reporting high and low performance of faculty

Table 5. Factors affecting students' perception of the performance of faculty members as PBL facilitators $(n=348)$

\begin{tabular}{|c|c|c|c|c|}
\hline \multirow{2}{*}{ Variables } & \multicolumn{2}{|c|}{ Faculty Members Performance } & \multirow{2}{*}{$\mathrm{Chi}^{2}$} & \multirow{2}{*}{ p-value } \\
\hline & Sufficient to High & Low or Insufficient & & \\
\hline \multicolumn{5}{|l|}{ School Year } \\
\hline Year 3 & $41(45.1 \%)$ & $50(54.9 \%)$ & \multirow{5}{*}{2.71} & \multirow{5}{*}{0.44} \\
\hline Year 4 & $21(32.3 \%)$ & $44(67.7 \%)$ & & \\
\hline & & & & \\
\hline Year 5 & $37(37.8 \%)$ & $61(62.2 \%)$ & & \\
\hline Year 6 & $36(38.3 \%)$ & $58(61.7 \%)$ & & \\
\hline \multicolumn{5}{|l|}{ Gender } \\
\hline Female & $91(40.3 \%)$ & $135(59.7 \%)$ & \multirow{3}{*}{0.59} & \multirow{3}{*}{0.44} \\
\hline & & & & \\
\hline Male & $44(36.1 \%)$ & $78(63.9 \%)$ & & \\
\hline \multicolumn{5}{|c|}{ Previous GPA } \\
\hline $4-5$ & $88(42.3 \%)$ & $120(57.7 \%)$ & \multirow{3}{*}{2.69} & \multirow{3}{*}{0.26} \\
\hline $3-<4$ & $40(33.6 \%)$ & $79(66.4 \%)$ & & \\
\hline$<3$ & $7(33.3 \%)$ & $14(66.7 \%)$ & & \\
\hline
\end{tabular}


Table 6. Factors affecting students 'perception of the performance of teaching assistants as PBL facilitators $(n=348)$

\begin{tabular}{|c|c|c|c|c|}
\hline \multirow{2}{*}{ Variables } & \multicolumn{2}{|c|}{ Teaching Assistants Performance } & \multirow{2}{*}{$\mathrm{Chi}^{2}$} & \multirow{2}{*}{ p-value } \\
\hline & Sufficient to High & Low or Insufficient & & \\
\hline \multicolumn{5}{|l|}{ School Year } \\
\hline Year 3 & $56(61.5 \%)$ & $35(38.4 \%)$ & \multirow{5}{*}{2.53} & \multirow{5}{*}{0.47} \\
\hline Year 4 & $39(60 \%)$ & $26(40 \%)$ & & \\
\hline & & & & \\
\hline Year 5 & $61(62.2 \%)$ & $37(37.8 \%)$ & & \\
\hline Year 6 & $49(52.1 \%)$ & $45(47.9 \%)$ & & \\
\hline \multicolumn{5}{|l|}{ Gender } \\
\hline Female & $135(59.7 \%)$ & $91(40.3 \%)$ & \multirow{3}{*}{0.182} & \multirow{3}{*}{0.67} \\
\hline & & & & \\
\hline Male & $70(57.4 \%)$ & $52(42.6 \%)$ & & \\
\hline \multicolumn{5}{|c|}{ Previous GPA } \\
\hline $4-5$ & $131(63 \%)$ & $77(37 \%)$ & \multirow{3}{*}{3.73} & \multirow{3}{*}{0.16} \\
\hline $3-<4$ & $62(52.1 \%)$ & $57(47.9 \%)$ & & \\
\hline$<3$ & $12(57.1 \%)$ & $9(42.9 \%)$ & & \\
\hline
\end{tabular}

members and teaching assistants among students> gender, school year, and their previous GPA.

\section{Discussion}

Problem based learning (PBL) is a strategy of learning that is widely used in health professions education globally and is now one of the main learning strategies in Saudi medical schools $\underline{15}$. Undergraduate Saudi medical students were found to be satisfied with the PBL strategy. Among the sources of this satisfaction was the facilitation skills of the class tutors $\frac{16,17}{}$. The PBL tutor is one of the angles of success in a PBL curriculum, in addition to the student and the educational problem. So, the skilled tutor plays an essential role in the success of the PBL sessions ${ }^{18,19}$.

In this study, we assessed the performance of faculty members and teaching assistants as class tutors based on the perception of the medical students. Data was collected through a questionnaire crafted by the researchers. Reliability study revealed high consistency of the questionnaire (Cronbach's alpha is 0.928) and validation through exploratory factor analysis (EFA) gave item loadings under three factors (components) and no 
items were discarded from the analysis. So, our tool was proved to be valid and reliable.

The results of this study revealed that the TAs were perceived more positively than faculty members as PBL class tutors. This finding is congruent with a study conducted at a medical college in Pakistan and compared the teaching assistants versus faculty member's facilitation skills in PBL tutorial sessions ${ }^{20}$. In another study, Steele et al. ${ }^{21}$ stated that the better achievement of the learning outcomes for the students taught by studentled PBL tutorials that other students who were taught by faculty-led PBL tutorials. However, the difference was not statistically significant.

TAs appear to show better facilitation skills in PBL tutorials, especially in guiding student groups through interactive two-way discussion, identifying the students' misconceptions, and giving constructive feedback on their performance during tutorial sessions. This can be explained by the fact that TAs are closer to the students in age and thinking and the students are more likely to be open with them than with faculty members. As such, TAs were described as 'student-directed tutors' who, according to Wilkerson et al., 1991, guide the work of the group and facilitate self-directed learning, which are the hallmarks of effective PBL ${ }^{22}$. Moreover, Neville, 1999 argued that faculty may be so wary of falling into their natural directive role that they adopt a completely "handsoff" approach, failing to guide students when necessary ${ }^{23}$. Furthermore, Groves et al. $\underline{24}$ found subject expertise affects tutor's facilitation skills as they tend to use their subject-matter knowledge considerably compared to nonsubject expert. In the context, Nagraj et al. $\frac{25}{\text { reported that }}$ the students 'evaluation for the performance of the tutor was more positive for near-peer PBL tutors compared to staff tutors $\underline{25}$.

Regarding the expertise and qualifications of faculty tutors, Silver and Wilkerson ${ }^{26}$ and Chung et al. 27 argued that expertise detracts from a tutor's role as a facilitator and tutors' qualifications are not significantly associated with students' perception of their performance. On the other hand, Maudsley ${ }^{28}$ argued that faculty members who have also training in PBL facilitation are more likely to be better PBL tutors.

Regarding the factors that might affect students' perception of tutor facilitation skills, the current study did not find any significant differences based on students〉 gender, school year, and previous GPA. This is contradicting with the results of Aldayel et al. $\underline{29}$, who reported that students' perception of tutors' facilitation skills was affected by their previous GPA.

\section{Conclusion}

Perception of the medical students of the PBL facilitation skills of teaching assistants was more positive that their perception of those skills of faculty members. Teaching assistants are suitable PBL facilitators probably because they have better understanding of students' needs than faculty members, being closer to them in age or their recent experience as undergraduate medical students. Further, in-depth studies are recommended to address the factors affecting the facilitation skills PBL tutors and the reasons behind students' preference of teaching assistants more than faculty members in facilitating PBL tutorials.

Further studies are recommended on a larger sample size, and the investigated factors that may affect the level of performance should be associated with the tutors, not the students, to determine the factors that made teaching assistance of higher performance than faculty members.

\section{References}

1. Taylor D, Miflin B. Problem-based learning: Where are we now? Medical Teacher. 2008; 30(8):742-763. https://doi. org/10.1080/01421590802217199. PMid:18946818.

2. Colliver J. Effectiveness of problem-based learning curricula: Research and theory. Academic Medicine. 2000; 75:259-266. https://doi.org/10.1097/00001888200003000-00017. PMid:10724315.

3. Strobel J, van Barneveld A. When is PBL more effective? A meta-synthesis of meta-analyses comparing PBL to conventional classrooms. The Interdisciplinary Journal of Problem-based Learning. 2009; 3(1):44-58. https:// doi.org/10.7771/1541-5015.1046.

4. Amin Z, Hoon E. Basics in medical education. Journal of Educational Evaluation for Health Professions. 2011; 8:8. https://doi.org/10.3352/jeehp.2011.8.8. PMCid:PMC3152971. 
5. Ding X, Zhao L, Chu H, Tong N, Ni C, Hu Z, et al. Assessing the effectiveness of problem-based learning of preventive medicine education in China. Scientific Reports. 2015; 4:5126. https://doi.org/10.1038/ srep05126. PMid:24874915 PMCid:PMC4038805.

6. Chan LC. The role of a PBL tutor: a personal perspective. The Kaohsiung Journal of Medical Sciences. 2008; 24(3):S34-S38. https://doi.org/10.1016/S1607551X(08)70092-5.

7. Baroffio A, Nendaz M, Perrier, Nu V. Tutor training, evaluation criteria and teaching environment influence students' ratings of tutor feedback in problem-based learning. Advances in Health Sciences Education Theory Practice. 2007; 12(4):427-439. https://doi.org/10.1007/ s10459-006-9008-4. PMid:16847731.

8. Leary H, Walker A, Shelton B, Fitt M. Exploring the relationships between tutor background, tutor training, and student learning: A problem-based learning meta-analysis. The Interdisciplinary Journal of Problem-based Learning. 2013; 7(1):40-66. https://doi. org/10.7771/1541-5015.1331.

9. Johnson SM, Finucane PM. The emergence of problembased learning in medical education. Journal of Evaluation in Clinical Practice. 2001; 6(3):281-291. https://doi.org/10.1046/j.1365-2753.2000.00267.x. PMid:11083039.

10. Grave WS, Moust JHC, Hommes JA. The role of the tutor in a problem based learning curriculum. Maastricht University, Department of Educational Development and Research. 2003; 10-12.

11. Khan KN, Saeed SA, Frossard P. Recent medical graduates as facilitators in a PBL curriculum. Medical Education. 2006; 40:1128-1128. https://doi.org/10.1111/j.13652929.2006.02575.x. PMid:17054627.

12. Dawson-Saunders B, Trapp RG. Basic and clinical biostatistics, Norwalk: Appleton and Lange Publications. 1994. https://doi.org/10.1002/sim.4780101016.

13. IBM Corp. Released 2017. IBM SPSS Statistics for Windows, Version 25.0. Armonk, NY: IBM Corp. [Internet]. Available from: https://www.ibm.com/ support/pages/how-cite-ibm-spss-statistics-or-earlierversions-spss.

14. World Medical Association Declaration of Helsinki: Ethical Principles for Medical Research Involving Human Subjects [Internet]. 2008. Available from: https://www.wma.net/policies-post/wma-declaration- of-helsinki-ethical-principles-for-medical-researchinvolving-human-subjects/.

15. Al Haqwi AI, Mohamed TA, Al Kabba AF, Alotaibi SS, Al Shehri AM, Abdulghani HM, Badri M. Problem-based learning in undergraduate medical education in Saudi Arabia: Time has come to reflect on the experience. Medical Teacher. 2015; 37(1):S61-66. https://doi.org/10. 3109/0142159X.2015.1006608. PMid:25803592.

16. Al-Damegh SA, Baig LA. Comparison of an integrated problem-based learning curriculum with the traditional discipline-based curriculum in KSA. Journal of College of Physicians and Surgeons Pakistan. 2005; 15(10):605608. https://pubmed.ncbi.nlm.nih.gov/19810296/.

17. Shamsan B, Sayed AT. Evaluation of problem-based learning course at College of Medicine, Qassim University, Saudi Arabia. International Journal of Health Sciences. 2009; 3(2):249-258. https://www.ncbi.nlm.nih. gov/pmc/articles/PMC3068813/.

18. Musal B, Gursel Y, Ozan S, Taskiran HC, Van Berkel H. The satisfaction levels of students on academic support and facilities, educational activities, and tutor performance in a PBL Program. International Association of Medical Science Educators. 2006; 16(1):35-42.

19. Al-Drees AA, Khalil MS, Irshad M, Abdulghani HM. Students' perception towards the problem-based learning tutorial session in a system-based hybrid curriculum. Saudi Medical Journal. 2015; 36(3):341-348. https:// doi.org/10.15537/smj.2015.3.10216. PMid:25737178 PMCid:PMC4381020.

20. Saeed SA, Zia N, Qazi Y. Facilitation skills of basic sciences faculty and fresh medical graduates: An AKU experience. Procedia-Social and Behavioral Sciences. 2010; 2(2):1316-20. https://doi.org/10.1016/j. sbspro.2010.03.193.

21. Steele DJ, Medder JD, Turner P: A comparison of learning outcomes and attitudes in student- versus faculty-led problem- based learning: an experimental study. Medical Education. 2000; 34(1):23-29. https://doi.org/10.1046/ j.1365-2923.2000.00460.x. PMid:10607275.

22. Wilkerson L, Hailer JP, Liu P. A case study of studentdirected discussion in four problem-based tutorial groups. Academic Medicine. 1991; 66(9):S79-S81. https://doi.org/10.1097/00001888-199109000-00048. PMid:1930538.

23. Neville AJ. The problem-based learning tutor: Teacher? Facilitator? Evaluator? Medical Teacher. 1999; 21(4):393401. https://doi.org/10.1080/01421599979338. 
24. Groves M, Régo P, O'Rourke P. Tutoring in problembased learning medical curricula: The influence of tutor background and style on effectiveness. BMC Medical Education. 2005; 5(1):1-7. https://doi.org/10.1186/14726920-5-20. PMid:15938758 PMCid:PMC1180438.

25. Nagraj S, Miles S, Bryant P, Holland R. Medical students' views about having different types of problem-based learning tutors. Medical Science Educator. 2019; 29(1):93-100. https://doi.org/10.1007/s40670-01800634-9.

26. Silver M, Wilkerson L. Effects of tutors with subject expertise on the problem- based tutorial process. Academic Medicine. 1991; 66(5):298-300. https:// doi.org/10.1097/00001888-199105000-00017. PMid:2025366.

27. Chung EK, Hitchcock MA, Oh SA, Han ER, Woo YJ. The relationship between student perceptions of tutor performance and tutors' background in problem-based learning in South Korea. International Journal of Medical Education. 2011; 2:7-11. https://doi.org/10.5116/ ijme.4d38.d07e.

28. Maudsley G. Roles and responsibilities of the problembased learning tutor in the undergraduate medical curriculum. BMJ. 1999; 318(7184): 657-661. https:// doi.org/10.1136/bmj.318.7184.657. PMid:10066213 PMCid:PMC1115096.

29. Aldayel AA, Alali AO, Altuwaim AA, Alhussain HA, Aljasser KA, Abdulrahman KA, et al. Problem-based learning: medical students' perception toward their educational environment at Al-Imam Mohammad Ibn Saud Islamic University. Advances in Medical Education and Practice. 2019; 10:95-104. https:// doi.org/10.2147/AMEP.S189062.PMid:30881170 PMCid:PMC6396659 